\title{
Change and Preservation in Language, Literature and Culture in Southeast Asia: Trends and Directions
}

\author{
GRACE VS CHIN \\ ${ }^{*}$ KUMARAN RAJANDRAN \\ School of Humanities, Universiti Sains Malaysia, 11800 USM, Pulau Pinang, Malaysia \\ "Corresponding author: rkumaran@usm.my
}

Published online: 20 October 2020

To cite this article: Grace VS Chin and Kumaran Rajandran. 2020. Change and preservation in language, literature and culture in Southeast Asia: Trends and directions. KEMANUSIAAN the Asian Journal of Humanities 27(2): 79-101. https://doi.org/10.21315/kajh2020.27.2.5

To link to this article: https://doi.org/10.21315/kajh2020.27.2.5

\section{Introduction}

The theme of "Change and Preservation" was developed for the Fifth International Conference on Linguistics, Literature and Culture (ICLLIC), which took place in the United Nations Educational, Scientific and Cultural Organisation (UNESCO) World Heritage Site of George Town in Pulau Pinang, Malaysia, from 29th to 30th July 2019. ICLLIC is organised by the English Language Studies Department of the School of Humanities at Universiti Sains Malaysia and was the brainchild of Shakila Abdul Manan, a former Professor of English Language Studies. She inspired and encouraged the department to organise ICLLIC, aiming to galvanise research and build networks among researchers in Malaysia and Southeast Asia. As such, ICLLIC has conventionally received strong participation from academics and postgraduate students in this region, particularly Malaysia, Indonesia, the Philippines and Thailand, even though it emphasises research in Asia as a whole. The success of the ICLLIC series throughout the years has also encouraged the English Language Studies Section to continue organising the conference.

ICLLIC has been a biannual conference since its inception in 2010 (ICLLIC 2010), with subsequent conferences held in 2012, 2014 (ICLLIC 2014) and 2016 (ICLLIC 2016). These four previous conferences provided a critical space for the sharing and exchanging of ideas and knowledge through presentations, which later resulted in two edited books and two journal publications. ICLLIC 2010 and ICLLIC 2012 respectively produced two edited books, titled Linguistics, Literature and Culture: Millennium Realities and Innovative Practices in Asia (2012) and Research Mosaics of Language Studies in Asia: Differences and 
Diversity (2019). ICLLIC 2014 published Mapping the Spectrum: Current and Emerging Perspectives in Linguistics, Literature and Culture (2015) as a journal special issue and ICLLIC 2016 published a special issue of KEMANUSIAAN the Asian Journal of Humanities, titled Linguistics, Literature and Culture: Interactions between the Global and the Local (2016). While the 2016 special issue focuses on local-global links and tensions, the current volume of papers from ICLLIC 2019 explores change and preservation and their interconnections with local-global dynamics, including causes and effects. In general, the four previous publications not only capture the diversity of ideas available at ICLLIC, but also help document important work in progress in the research fields of language and literature in Asia. Hence, the fifth ICLLIC and particularly the articles in this theme continue in the tradition of its predecessors.

The fifth ICLLIC inquires about the roles and manifestations of language, literature and culture in Asia, primarily Southeast Asia, by focusing on the theme of "Change and Preservation". Topical and relevant, the theme aptly captures the disjunctive and fluid spaces and contexts of the fast-changing, diasporic and globalising landscapes of Asia as well as the debates, issues and challenges that have emerged in recent decades. Calling for participants to "investigate how identities, values and other related discourses are defined, negotiated or articulated through the theme of change and preservation" (ICLLIC 2019), the conference aims to open up a critical space of dialogue and discussion through which this theme can be interrogated, examined or explored in the mentioned disciplinary fields.

\section{Why Change and Preservation?}

Asia has charted a phenomenal rise in economic strength since the late 1960s, when it was considered the "poorest continent in the world when it came to income levels" (Nayyar 2019). In the past five decades, this "poorest" region has experienced unprecedented transitions and transformations in income levels and lifestyles. Japan has long been recognised as one of the first developed nations in Asia. Since the 1970s, Japan was also the world's second largest economy until it was overtaken by China in 2010. The 1990s saw the emergence of the "miracle" economies of Singapore, Taiwan, Hong Kong and South Korea-also known as the "Four Asian Tigers"-while the millennium witnessed new heavyweight players entering the global economy, notably China and India. Asia was in fact predicted to achieve the world's largest gross domestic product (GDP) by 2020 (Yendamuri and Ingilizian 2019), until the 2019 novel coronavirus or COVID-19 pandemic knocked this projection off course. 
This narrative of capitalistic wealth and economic success is an impressive one, especially given the ethnolinguistic, social, cultural and religious diversity and plurality of Asia. In the past decade, this narrative has inspired literary works that revolve around Asian wealth, materialism and excess, including Kevin Kwan's Crazy Rich Asians trilogy (2013-2017), Tash Aw's Five Star Billionaire (2013), Cheryl Lu-Lien Tan's Sarong Party Girls (2016) and Diksha Basu's The Windfall (2017). However, these material developments should not mask the disparities in class, education, health, income and living standards in Asia (United Nations Development Programme 2020), in addition to the social ills of poverty and rising crime rates, which can be attributed to colonial and inherited burdens of race, gender and class, and the uneven rates of economic development and political engagement across the region. The imbalances and inequalities engendered by global capitalism and labour markets have further contributed to the exploitation and subjugation of the weak and vulnerable - seen in modern slavery and human trafficking networks - as well as rising environmental denigration and destruction. The positivist narrative of Asia's capitalistic success should thus be tempered with an acknowledgement of the intertwining darker and negative aspects of modernisation and economic development.

The profound effects of late capitalism and globalisation aside, the giant strides made in Asia have also been made possible by the major advances in the Internet and communicative and visual technologies. The economic, technological and ideological impact and influence of these discourses and developments on "third world" or growing Asian cultures and societies cannot be understated, as they affect and change not only cultures and societies but also influence and shape identities across the region, in both public and private spaces, and at every level, from the state to society and the individual. In other words, these profound changes have rewired the ways in which "we perceive ourselves and the world, how we connect with each other and how we should live" (ICLLIC 2019). Modernisation, westernisation, development, transnationalism, glocalisation and globalisation have become keywords in the observation of Asian nations caught in the throes of transition and transformation, while academic studies across disciplinary fields strive to examine and capture the new social and cultural formations and transformations occurring in an increasingly fluid, postmodernist landscape:

In this new, fast-paced reality that we live in, culture is claimed to be transformative (and not static), contentious (and not just congratulatory) and heterogeneous (and not only homogeneous). This notion of culture calls for a global cultural consciousness which requires people to interact appropriately with new cultures that are different from their own and to continuously adapt and re-adapt to the incessant changes that take place. (ICLLIC 2019) 
Yet, change is not without its challenges as it also engenders instability and anxiety. As a result, the celebratory or positivist view of Asia's rapid change and transformation has been countered by claims of flux, volatility, uncertainty and insecurity as well articulations of fear, angst, discomfort, ambivalence, ambiguity, opposition and resistance, especially in relation to the contentious identity categories of language, race and ethnicity, gender, sexuality, religion and culture. Indeed, the need to preserve traditional cultures and values has been used as rallying cry by postcolonial states and governments as the basis of nationalism. In his famous rebuttal against Anderson's $(1983,6)$ famous concept of the nation as an "imagined political community", prominent theorist Partha Chatterjee in Whose Imagined Community? (1996) observes that the grand projects of independence and nation-building are also projects of decolonisation and "anti-colonial nationalism" (Chatterjee 1996, 216), whereby the once colonised subjects can assert their identities and sovereignty based on difference. $\mathrm{He}$ furthermore contends that anti-colonial nationalism is achieved by negotiating between two domains: the material and the spiritual. The former is dominated by western economy, science and technology: essentially, the domain where the influences of the West can be found, including their colonial legacies. The latter however "[bears] the 'essential' marks of cultural identity" (Chatterjee 1996, 217). The spiritual domain, which also forms the heart of anti-colonial resistance, is represented by the space of indigenous and/or local culture. Potent symbols of the spiritual domain include the patriarchal, heteronormative family as well as identity markers like language, customs, rituals, values and traditions.

In Southeast Asia, affirmations of the spiritual domain can still be seen in nations like Malaysia, Indonesia, Brunei Darussalam (henceforth Brunei) and the Philippines, all of which have held onto religious and cultural identities, values and traditions, and have instituted them through policies, law or official state discourses. Policies on national language and national culture in Malaysia, for instance, preserve and uphold the language and culture of Malay Muslims who form the ethnic and religious majority in the country. The ruling of Brunei and its citizens revolves around the national tripartite ideology of Melayu Islam Beraja (Malay Islamic Monarchy), which privileges the hegemonic identity of the Brunei Malay through the validation of Malay language and culture, Islamic practices and values and the monarchical government. The conservative discourse of the family is also very strong in many Southeast Asian societies. In the Philippines, the family is powerfully enshrined as the "foundation of the nation" (Article XV Sec. 1) in its Constitution. Dominant state ideologies of the family have also prevailed in Indonesia, with family harmony and unity promoted through discourses that include state ibuism (motherhood) and Islamic concepts of Keluarga Sakinah (harmonious family) and Keluarga Maslahah (virtuous family). At the same time, 
the "cultural discourses of honour and shame" (Chin and Kathrina 2018, 5) that regulate ethnic, gender and sexual identities and behaviour have remained strong in conservative Asian societies. Such ideologies and discourses also underscore the strength of collectivist traditions and practices that make up identities and communities in many parts of Asia, despite the changes and transformations wrought by modernisation, westernisation, economic progress and globalisation.

Language is often part of the debate about identity in Asia - be it ethnic, national, regional or religious. Newly-independent countries often favour local languages, such as Tagalog in the Philippines, Malay in Brunei, Indonesia and Malaysia, and Hindi in India or Sinhala in Sri Lanka. Yet, these languages are majoritarian while other languages were, and still are, often marginalised. The conflicts over language, ethnicity and culture have also led to riots or war such as in India and Sri Lanka. The promotion of a language as "national" or "official" expanded the space for one language but contracted the space for other languages. Compromise is often espoused, while colonial languages are (re)introduced. English is a link language in India and Sri Lanka, a prominent second language in the Philippines, Malaysia and Brunei and one of the official languages of Singapore. However, English is no longer as "foreign" and "threatening" as before because like many other languages, English has followed the trend of becoming localised, having engendered varieties across Asia (Nelson, Proshina and Davis 2020). Its localisation demonstrates the ability of Asian societies to adapt and adopt English and other colonial languages to suit their circumstances. Although the above overview offers only a small glimpse into the issues and challenges that have emerged in Asia, it more importantly reveals how change and preservation co-exist in an uneasy relationship that can be fraught with tension, ambiguity, ambivalence, and sometimes, even conflict.

Heavily contested and debated, "change" and "preservation" as key terms and discourses in academia must thus be defined according to the contextual specificities and discursive particularities of localised histories, cultures and geopolitics, especially when one takes into account Asia's rich background: the cradle of some of the world's oldest cultures and most ancient civilisations, the birthplace of major religions that include Hinduism, Buddhism, Christianity and Islam, the site of war and conquest, imperialism and colonisation (not just by western powers but also within borders and among neighbouring territories) as well as migration and diaspora and their attendant developments, including assimilation, acculturation and hybridity. The study or analysis of change and preservation should not only consider the ways in which they are perceived, negotiated, shaped and articulated in distinct ways and in varying contexts, but also how they are informed by colonial and national memories, imaginaries, 
histories and legacies, indigenous cultures, practices and identities (also the hallmarks of the "spiritual" domain), and the country's own political vision and ambition as well as developing and modernising needs - a point especially relevant to developing third world economies and societies in the region.

As the organising theme of the fifth ICLLIC, "Change and Preservation" therefore provides the participants a suitably wide scope and range through which they can examine and explore myriad topics and issues in the disciplinary fields of language, literature and culture. A glance at the extended abstracts published in the edited e-proceedings titled Change and Preservation in Language and Culture in Asia (Asl, Rajandran and Azam 2019) shows the diverse perspectives and responses to the theme. At the same time, we have curated five peer-reviewed articles from selected conference speakers and participants, which are featured in this issue of KEMANUSIAAN the Asian Journal of Humanities. Though limited in number, the articles here nonetheless shed light on new and exciting research directions in the fields of language, literature and culture.

\section{Research Trends and Directions in Southeast Asia}

While the primary aim of this theme is to showcase selected articles produced by conference speakers and participants, we also wish to contribute in our own small way to the main conference objective of "developing new knowledges" by identifying major research trends and directions in the study of language, literature and culture from the 1990s until 2020, with the main spotlight on Southeast Asia, also the location of the fifth ICLLIC. Asia is so diverse and vast that the task of reviewing or even introducing the considerable body of scholarship in the region in just one article would be presumptuous, not to mention inadequate. Instead, we aim to introduce a sample of interesting and relevant research that is linked to the focus of the fifth ICLLIC. We will furthermore limit the field to research monographs and edited volumes and only those produced in English, not just because it is the language of international scholarship but also because the language barrier prevents us from accessing many fine works produced by local scholars and academics in their native languages from around the region. Using these sample studies, we address the following questions: (1) How has the study of language, literature and culture changed in recent decades? and (2) What has been preserved or maintained in these studies?

Since the 1990s, there has been a substantial corpus of critical scholarship that engages with Southeast Asia's fluid and changing societies and cultures as well as the resulting contestations, challenges and resistances in the name of tradition, preservation and continuity, among others. Notably, this corpus is dominated 
by the postcolonial turn, which emerged in the 1980s as a result of prominent cultural and literary theorists like Edward W Said, Homi K Bhabha and Gayatri Chakravorty Spivak, who also formed the "foundation" (Bachmann-Medick 2016, 134) of Postcolonial Studies. The formation of this field was also augmented by the works of other renowned Indian theorists, including Partha Chatterjee, Braj B Kachru and Chandra Talpade Mohanty, as well as seminal works such as Ashcroft, Griffiths and Tiffin's The Empire Writes Back: Theory and Practice in Post-Colonial Literatures (1989). These developments significantly impacted the academic disciplines of English Literature and English Studies (see Slemon 2015) and helped pave the way for the growing scholarship in the study of postcolonial languages, literatures and cultures in the region and especially in countries formerly colonised by anglophone cultures like Great Britain and the United States of America (USA).

The emergence of Postcolonial Studies as a leading research direction is particularly relevant to Asia and especially Southeast Asia. With the exception of Thailand, all of the Southeast Asian nations have historically been colonised by western powers, a profound experience that has powerfully affected the mentality, emotions and psychology of colonised subjects, to say nothing of the ways in which their identities and lives have been altered and reshaped. These weighty colonial legacies have also contributed to the construction of postcolonial landscapes in the contexts of (post-)independence, nation-building, modernisation and development projects - exemplified for instance by prevailing western structures and styles seen in the systems of government, education, law and infrastructure, among others, across the region. Moreover, these legacies have continued in the insidious guise of neo-colonising and neoliberal forces in the post-independence age and their far-reaching influences are still evident in the ideologies and discourses of race, gender, sexuality and class, and their attendant epistemological hierarchies, imbalances and biases. Studies in the fields of language, literature and culture not only reflect these momentous shifts and transformations across the colonialpostcolonial temporal spectrum but have also actively engaged with and are informed by the corresponding discourses and practices on the ground.

In the field of Postcolonial Studies in Southeast Asian literatures and cultures, one major trend is the grouping of studies according to language and country. For instance, the English-language scholarship is very productive in countries once colonised by the British and the USA - Malaysia, Singapore and the Philippinesand notably in the academic disciplines of English Studies, English Language and Linguistics and English Literature. Due to their shared anglophone heritage, studies on Malaysia, Singapore and the Philippines have appeared as research based on either a single country or a comparison of two or even all three of these 
countries. Key comparative Postcolonial Studies in the anglophone literatures and cultures of these countries include Lim's Nationalism and Literature: EnglishLanguage Writing from the Philippines and Singapore (1993) and Writing S.E./ Asia in English: Against the Grain, Focus on Asian-English-Language Literature (1994), Tope's (Un)framing Southeast Asia: Nationalism and the Post-Colonial Text in English in Singapore, Malaysia and the Philippines (1998), Lo's Staging Nation: English Language Theatre in Malaysia and Singapore (2004); Puthucheary's Different Voices: The Singaporean/Malaysian Novel (2009), Patke and Holden's The Routledge Concise History of Southeast Asian Writing in English (2010) and Tay's Colony, Nation and Globalisation: Not at Home in Singaporean and Malaysian Literature (2011).

Country-based Postcolonial Studies in anglophone literatures and cultures are also considerable. In the study of Malaysian Literature in English, we have Mohammad A. Quayum and Wicks' edited Malaysian Literature in English: A Critical Reader (2001), Nor Faridah and Mohammad A. Quayum's Colonial to Global: Malaysian Women's Writing in English 1940s-1990s (2003), Pillai's Colonial Visions, Postcolonial Revisions: Images of the Indian Diaspora in Malaysia (2007) and Ng's Intimating the Sacred: Religion in English Language Malaysian Fiction (2011), among others. Research on Singaporean Literature in English can be found in Koh's Singapore Literature in English: An Annotated Bibliography (2008). Poon and Whitehead's edited volume, Singapore Literature and Culture: New Directions in Local and Global Contexts (2017) and the ambitious series of eight edited volumes titled Interlogue: Studies in Singapore literature (1998-2009). The Philippines is the site of some of the most exciting research in anglophone postcolonial literature in the region, such as Hidalgo's Philippine Post-colonial Studies: Essays on Language and Literature (1993) and A Gentle Subversion: Essays on Philippine Fiction in English (1998). There are also Abad and Hidalgo's Our People's Story: Philippine Literature in English (2003), Pison's Dangerous Liaisons: Sexing the Nation in Novels by Philippine Women Writers, 1993-2006 (2010) and Garcia's At Home in Unhomeliness: Rethinking the Universal in Philippine Postcolonial Poetry in English (2007) and Aura: The Gay Theme in Philippine Fiction in English (2012).

Until today, the scholarship focusing on postcolonial theories and approaches is still robust and rigorous and attests to the dominance and influence of the postcolonial turn not only in regional higher institutions, but also across the fields of arts, humanities and social sciences. As a result, many of the studies categorised under the rubric of "postcolonialism" also use multidisciplinary, interdisciplinary and cross-disciplinary approaches and frameworks - another major trend that has been maintained since the 1990s. The influence of Postcolonial Studies can 
thus be seen across the disciplinary spectrum, including Gender Studies, Race and Ethnicity, Cultural Studies, Diaspora and Transnational Studies as well as Translation Studies. A sample of such works in Southeast Asian literatures and cultures are Zawiah Yahya's Resisting Colonialist Discourse (1994), Hau's Necessary Fictions: Philippine Literature and the Nation, 1946-1980 (2000) and On the Subject of the Nation: Filipino Writings from the Margin, 1981-2004 (2004), Wong's Post-Colonial Chinese Literatures in Singapore and Malaysia (2002), Lim's Overcoming Passion for Race in Malaysian Cultural Studies (2008), Goh, Gabrielpillai, Holden and Khoo's Race and Multiculturalism in Malaysia and Singapore (2009), Goh's Narrating Race: Asia, (Trans)nationalism, Social Change (2011), Hellwig's Women and Malay Voices: Undercurrent Murmurings in Indonesia's Colonial Past (2012), Bernards' Writing the South Seas: Imagining the Nanyang in Chinese and Southeast Asian Postcolonial Literature (2015) and Chin and Kathrina's The Southeast Asian Woman Writes Back: Gender, Identity and Nation in the Literatures of Brunei Darussalam, Malaysia, Singapore, Indonesia and the Philippines (2018).

Given the wealth of ethnolinguistic cultures and communities in the region, it is not surprising that Translation Studies has been established as another research direction, with literary translation as a significant area in the study of Southeast Asian literatures and cultures. Research involving translation has also been categorised under Comparative Studies/Literature, World Literature and CrossCultural Studies. Similarly too, the scholarship in this field has been invigorated by the multidisciplinary, interdisciplinary and cross-disciplinary approaches. One of the more recent trends that has emerged in the past decade is that of Sinophone Literature and Culture, which branched off from the popular field of Overseas Chinese or Chinese Diaspora Studies. Maintaining the focus on the Chinese diasporic communities in Southeast Asia and their cultural and literary productions, works in this category also straddle Race and Ethnicity Studies and Diaspora and Transnational Studies, with language as the main frame of reference. Examples include Groppe's Sinophone Malaysian Literature: Not Made in China (2013), Tan's Rethinking Chineseness: Translational Sinophone Identities in the Nanyang Literary World (2013) and Wai Siam Hee's Remapping the Sinophone: The Cultural Production of Chinese-Language Cinema in Singapore and Malaya before and during the Cold War (2019).

Translation Studies that revolve around Malay and Islamic literature and culture form another common trend, with scholarly productions informed mainly by Malay/Melayu/Bahasa and Muslim cultures and traditions of the following Southeast Asian countries: Malaysia, Indonesia and Brunei. Scholarly works in this category include Braginsky's The System of Classical Malay Literature 
(1993) and The Heritage of Traditional Malay Literature: A Historical Survey of Genres, Writings and Literary Views (2004), Maier's We are Playing Relatives: A Survey of Malay Writing (2004), Arimbi's Reading Contemporary Indonesian Muslim Women Writers: Representation, Identity and Religion of Muslim Women in Indonesian Fiction (2009), Zawiah's Reading Approaches in Malay Literature (2010), Hijjas' Victorious Wives: The Disguised Heroine in Nineteenth-Century Malay Syair (2010), Ricci's Islam Translated: Literature, Conversion and the Arabic Cosmopolis of South and Southeast Asia (2011), Mohamad Rashidi and Graf's Fiction and Faction in the Malay World (2013), Ding and van der Molen's Traces of the Ramayana and Mahabharata in Javanese and Malay Literature (2018) and Aveling's Perceptions: Essays on Translation and Literature of the Malay World (2019).

Indeed, regional and country-centred researches make up a vital portion of the studies in the translational, comparative and cross-cultural fields of literature and culture. Comparative research with a regional focus include Suryadinata's edited Chinese Adaptation and Diversity: Essays on Society and Literature in Indonesia, Malaysia \& Singapore (1993), Smyth's The Canon in Southeast Asian Literature: Literatures of Burma, Cambodia, Indonesia, Laos, Malaysia, Philippines, Thailand and Vietnam (2000), Lindsay's In Between Tongues: Translation and/ of/in Performance in Asia (2006), Yamada's Modern Short Fiction of Southeast Asia: A Literary History (2009), Lim and Yamamoto's Film in Contemporary Southeast Asia: Cultural Interpretation and Social Intervention (2012) and Chin's Translational Politics in Southeast Asian Literatures: Contesting Race, Gender and Sexuality (forthcoming). Country-centred scholarship can be seen in Ebihara, Mortland and Ledgerwood's Cambodian Culture Since 1975: Homeland and Exile (1994), Chigas's Tum Teav: A Translation and Analysis of a Cambodian Literary Classic (2005), Galam's The Promise of the Nation: Gender, History and Nationalism in Contemporary Ilokano Literature (2009), Platt's Isan Writers, Thai Literature: Writing and Regionalism in Modern Thailand (2013) and Ly's Traces of Trauma: Cambodian Visual Culture and National Identity in the Aftermath of Genocide (2020). It should also be noted that some of these studies can again be categorised under Comparative Studies and Cross-Cultural Studies, amongst others.

It would be remiss of us if we do not mention a key research direction that has gained some prominence in recent years, namely Queer Studies. Research on the lesbian, gay, bisexual, transgender and queer (or questioning) (LGBTQ) cultures of Southeast Asia forms one of the more recent scholarly trends and highlights more than ever the changing social and cultural spaces and identities of Southeast Asia and, by that extension, Asia. However, the field is a highly 
charged one due to the contestations and debates surrounding LGBTQ-related issues in Southeast Asia, where conservative values and religious viewpoints have informed perspectives and attitudes towards LGBTQ identities and communities. Until today, homosexuality is still criminalised in Singapore, Malaysia, Brunei and Myanmar as well as the Indonesian province of Aceh. On the other hand, Thailand and the Philippines have recently instituted laws that protect LGBTQ rights. The ways in which LGBTQ identities and communities are viewed and treated thus vary among countries in the region. Among the important studies that have been published are Garcia's Slip/Pages: Essays in Philippine Gay Criticism (1998) and Philippine Gay Culture: Binabae to Bakla, Silahis to MSM (2009), Sinnott's Toms and Dees: Transgender Identity and Female Same-Sex Relationships in Thailand (2004), Yue and Zubillaga-Pow's Queer Singapore: Illiberal Citizenship and Mediated Cultures (2012), Murtagh's Genders and Sexualities in Indonesian Cinema: Constructing Gay, Lesbi and Waria Identities on Screen (2013) and Jackson's First Queer Voices from Thailand: Uncle Go's Advice Columns for Gays, Lesbians and Kathoeys (2016).

Similar trends are noted for language-based studies, where postcolonial Southeast Asian countries established and expanded the study of local languages. Such studies were not entirely new, as the former colonialists often documented the languages of the region in their attempt to understand and govern their subjects (Noor 2019). In the post-independence age, the direction of research shifted as it no longer served a distant colonial capital but rather to the growing local and national interests of preserving and enriching local languages and the local knowledges they encapsulated. This type of research is invariably multidisciplinary, as it does not rely on one area of linguistics to understand languages and the practices associated with and enabled by languages.

The range of areas under language studies is numerous, such as the "core" linguistic areas of Phonetics, Morphology, Syntax, Semantics and Pragmatics and their application in Language Education, Translation, Discourse Studies and Sociolinguistics. The "core" linguistic areas are often described by typologies, giving detailed descriptions of languages in Southeast Asia. Among the works that present the grammars of national and official regional languages are Enfield's A Grammar of Lao (2007), Sneddon et al.'s Indonesian: A Comprehensive Grammar (2010), Smyth's Thai: An Essential Grammar (2014) and Jenny and Tun's Burmese: A Comprehensive Grammar (2016). The diverse languages in this region have additionally become the subject of typological study, such as Ewing's Grammar and Inference in Conversation: Identifying Clause Structure in Spoken Javanese (2005) and Asmah's The Mah Meri Language: An Introduction (2014). There is a need for more typological studies on non-national and non- 
official languages in the region (particularly endangered languages), which should be better catalogued as they may be at risk due to the shift to prescriptive dominant national and official languages. Of note too are trends in producing a wealth of monolingual and bilingual dictionaries and language-learning guides for Southeast Asian languages, such as Smyth and Kien's Tuttle Practical Cambodian Dictionary (1995), Dewan Bahasa dan Pustaka's monumental Kamus Dewan (2015) for Malay and Domigpe and Domingo's Elementary Tagalog (2015), besides publications like the Teach Yourself and Rosetta Stone series that include Southeast Asian languages. While these are not scholarly in the traditional sense, they nonetheless rely on academic research to come up with entries and lessons.

The application of linguistic concepts and theories is another prominent direction in research. This endeavour is multidisciplinary from the start as it explores how contextual factors impact linguistic features and vice versa. In the field of New or World Englishes, the study of how English - previously perceived as a colonial tongue - has developed beyond the British Isles to become a global or international language in the postcolonial, late-capitalist and contemporary age, is commonly analysed. Country-specific volumes are available, such as Deterding's Singapore English (2007), Bautista and Bolton's Philippine English: Linguistic and Literary Perspectives (2008), Lim, Pakir and Wee's English in Singapore: Modernity and Management (2010), Hajar and Shakila's English in Malaysia: Postcolonial and Beyond (2014) and Pillai's Malaysian English (2020).

Besides that, Language Education is a practical direction of research, especially in the region's postcolonial developing societies where citizens are educated and prepared for employment. Language Education is especially crucial because it concerns the medium through which knowledge is communicated. English is seen as the vehicle of science and technology-also the domain of the West and the "material" (Chatterjee 1996) - and has led to changes in education policy, as captured by Muller et al. in Innovating EFL Teaching in Asia (2012), Deterding in Misunderstandings in English as a Lingua Franca: An Analysis of ELF Interactions in South-East Asia (2013) and Murray and Scarino in Dynamic Ecologies: A Relational Perspective on Languages Education in the Asia-Pacific Region (2014). There remains a tussle between English and local languages in education, with some countries like Brunei and Singapore opting for English as the medium of instruction, while Malaysia keeps shifting between English and Malay for science and mathematics (Gill 2002; Pennycook 1994).

Developments in New Englishes and Language Education are often influenced by Language Policy, which involves major actors like governments but also other actors like families and institutions. Such policies and the environments 
they entail are studied in Rappa and Wee's Language Policy and Modernity in Southeast Asia: Malaysia, Philippines, Singapore and Thailand (2006), Simpson's grand overview in Language and Identity in Asia (2007), Zuraidah's English in Multicultural Malaysia (2011), Foulcher, Moriyama and Budiman's Words in Motion: Language and Discourse in Post-New Order Indonesia (2012), Low and Azirah's English in Southeast Asia: Features, Policy and Language in Use (2012) and Azirah and Leitner's English in Southeast Asia and ASEAN: Transformation of Language Habitats (2020). These studies bridge political economy and linguistics, revealing their dialectical relationship due to changes in government policies on language and in the social environment as the day-to-day and mundane use and practice of languages often reflect the effects of governance.

Discourse Studies is another thriving direction of research. Its multidisciplinary focus spans politics, economy and society because it does not emphasise a particular area of linguistics but rather how these areas come together to construe a perception of reality. Studies on discourse employ various concepts and theories, resulting in rich descriptions and interpretations of discourses in English and local languages. Among the works taking a discourse analytical perspective are Nguyen-Marshall's In Search of Moral Authority: The Discourse of Poverty, Poor Relief and Charity in French Colonial Vietnam (2008), Koh and Balasingamchow's Women and the Politics of Representation in Southeast Asia: Engendering Discourse in Singapore and Malaysia (2015), Kularb's Reporting Thailand's Southern Conflict: Mediating Political Dissent (2016), Bhatia et al.'s International Arbitration Discourse and Practices in Asia (2018) and Rajandran and Shakila's Discourses of Southeast Asia: A Social Semiotic Perspective (2019). These studies consider how word and phrase order and structure portray a particular construal of entities and events, which may influence our perception and behaviour. More of such research is required, considering the growth and spread of right-wing governments, political parties, rampant neoliberalism and social upheavals confronting the countries in this region.

The research conducted in the areas under language-based studies is extensive and should be guided by clear research principles. Tan and Lindsay's Babel or Behemoth: Language Trends in Asia (2003) and Juliana Othman and Maskanah Mohammad Lotfie's Research Design for Language Studies (2018) aim to remind researchers about these principles and to ensure the validity and replicability of their research. While original research is conducted in Southeast Asia due to the availability of rich data, there is a tendency of applying existing concepts and theories developed in Europe or North America onto data from the region. The wealth of data is undeniable, but would it be possible for future research to expand existing concepts and theories and to develop those that are Southeast Asian in 
origin? This is a direction that does not yet seem prominent in English-language scholarship from this region. While it could possibly exist in local scholarship produced in the local languages, the access to such works are limited due to the language barrier. Publications in English or translations into English may enhance the visibility of such scholarship in the future.

The works above explicitly or implicitly recognise the social aspects of language and literature. Clearly, language and literature exist in a specific social milieu, whose forces cannot be denied as they leave "traces" in texts that point to the discursive effects and contextual influences of culture and society. Although these two areas of investigation similarly involve a cognitive aspect, they have received little interest. Langacker (2013) and Stockwell (2019) respectively argue for a cognitive turn in linguistics and literature and their approach could enhance available analytical methods in these two areas. The interaction between social and cognitive aspects may explain choices in linguistic and literary texts, contributing to their discourse, genre and style. Understanding this interaction provides us with a different but complementary approach to language and literature. It also enables us to, possibly, go beyond the text analysis that is typical to linguistic and literary analyses and consider experimental and interactive methods with the actual users of linguistic and literary texts.

Based on the sample studies above, we can see how the scholarship on language, literature and culture has changed in recent decades and what has also been preserved in the process. Changes in the research fields are represented by the emerging trends and directions that also reveal and reflect the ways Southeast Asia has evolved: the increased prominence of Translation Studies and the emergence of Queer Studies. While translation has been around for a long time, the new and innovative theories, approaches and perspectives influenced by the translational turn in the late 1990s and early 2000s have also given rise to new areas of research, such as Sinophone Literature and Culture. Another important scholarly development is the field of Queer Studies, which reflects and engages the changing social and political realities of Southeast Asian societies and nations. Languagebased studies have also moved from descriptions of languages to more applied concerns that can be found in New or World Englishes, Language Education and Discourse Studies.

At the same time, we have also considered the kinds of scholarship that have been preserved - exemplified by the major or dominant directions and trends that have been upheld. The popularity of postcolonial approaches and theories in the study of literatures and cultures, for instance, attests to the dominance of Postcolonial Studies as a pre-eminent research field. Likewise, scholarly research based on 
country and language has been retained as a major approach and trend. This could be due to the fact that there is a wealth of locally or nationally developed linguistic, literary and cultural varieties and distinctions available for scholarly inquiry and analyses; but it also could be due to the language barrier that prevents foreign scholars from accessing materials and texts developed in local languages. It also underscores the fact that Southeast Asian scholars are perhaps best-equipped to discover and address local issues through their research and develop good work that can be shared with the international academic community, thereby mitigating the western-centric theories and views that still dominate certain disciplinary fields. Last but not least, we should bear in mind that the contentious and contested identity categories of language, race and ethnicity, gender, sexuality, religion and culture still form and inform influential terrains of academic scholarship in the study of Southeast Asian languages, literatures and cultures, as they engage with the critical and enduring questions of who we are, how "we perceive ourselves and the world, how we connect with each other and how we should live" (ICLLIC 2019).

\section{The Articles}

The following articles in this issue engage the theme of "change and preservation" in various ways: two with a literary focus and three with a linguistic focus. Featuring the latest research by seasoned and emerging scholars, these articles provide a window into the main research trends and directions in Asia; significantly, the focus is primarily on Southeast Asian contexts. This is a laudable endeavour because the research is directly relevant to Asian societies and tries to understand how local or regional concerns are articulated.

In literature, we have two articles that respectively discuss the ethics of postcolonial translation and resistance in Saudi women's life writing: "The Ethical Project of Cultural Translation" by Sharmani Patricia Gabriel, also an invited plenary speaker at the fifth ICLLIC and "Spaces of Change: Arab Women's Reconfigurations of Selfhood through Heterotopias in Manal al-Sharif's Daring to Drive" by Moussa Pourya Asl. Interrogating the racialised discourse of Bangsa Malaysia, Gabriel's article engages key postcolonial and translation theories and concepts to tackle the ethics of postcolonial translation, which, she argues, should engage with the minority and culturally different other. To do so, the postcolonial translator must resist traditional translation approaches to text and culture by adopting "a more contemplative and contingent model of 'carrying across' that affirms and respects difference". Asl on the other hand takes up the theme of gendered resistance and agency in his reading of Manal al-Sharif's memoir Daring to Drive (2017). Using Foucault's concept of heterotopic spaces, Asl shows how female subjects use 
and negotiate different spaces in order to challenge the patriarchal status quo and articulate new identities. By demonstrating Saudi women's resistance and agency not only in life writing but also in cyberspace, Asl challenges the prevailing stereotype of Saudi women as passive and powerless subjects.

The language-themed articles by Cortazzi and Jin, Deterding and Kanoksilapatham investigate the roles of English in various countries of Southeast Asia: Cortazzi and Jin for Malaysia, Deterding for Brunei and Kanoksilapatham for Thailand. The authors reveal the dichotomy of English in this region - important yet threatening. While the articles by Cortazzi and Jin as well as Kanoksilapatham argue about the importance of English, Deterding shows how English could threaten local languages. A balance for the roles of English is required, where the language can flourish in the linguistic ecology to enrich cultures and foster communication. Countries should employ the language for their benefit and the formulation and implementation of suitable policies have preoccupied governments since the independence of several Southeast Asian countries. Cortazzi and Jin write about "Good Teachers: Visions of Values and Virtues in University Student Metaphors". They elicit Malaysian university students' metaphors of teachers in English. Common metaphors are encountered, which cover the domains of aesthetic, affective, cognitive, moral-spiritual and socialcultural. The metaphors frame teachers and students, indicating the presumptive responsibilities the two parties have in education. Deterding's article "Indigenous Languages and English in the Globalised Modern Era in Brunei Darussalam" provides an overview of the state of seven indigenous languages and Brunei English. Among the seven indigenous languages, six are threatened with extinction and may not be considered "languages" but "dialects" of Malay by some people. In contrast, English thrives and has become nativised until a distinct Brunei English is discernible. Kanoksilapatham's "Local Culture Preservation Through Southern Thainess-Based English Lessons" gives a practical example of teaching elementary school students English using materials on the local environment in Thailand. Although a "foreign" language, English can be used to understand "local" culture. Incorporating local elements in English lessons improved students' vocabulary and helped them articulate Thai identity in English. These three articles by Cortazzi and Jin, Deterding and Kanoksilapatham demonstrate Halliday's (2010) notion of "appliable linguistics" as linguistic concepts, theories and methods are put to work in order to bring about an understanding of language use in Malaysia, Brunei and Thailand. 


\section{Conclusion}

The five articles by Gabriel, Asl, Cortazzi and Jin, Deterding, and Kanoksilapatham reflect current research trends and directions in language and literature in Asia and particularly Southeast Asia. They demonstrate the notion of "change and preservation", as intended in the fifth ICLLIC. Change is an inevitable leitmotif in communities, societies and nations, and it leaves explicit or implicit traces in their languages, literatures and cultures. But change is not based on a blank slate and is always in conversation with older and established practices. These practices may be preserved, as some irredentists or romanticists may prefer, but the material practices on the ground - as with cultures and societies - often, and invariably so, experience transition, change and transformation; otherwise, they risk becoming obsolete or fossilised, existing only as memory or ritual. As our discussion of the major research trends and directions also show, a vibrant scholarship must consider the interplay of change and preservation and be grounded in the discursive realities of the societies it studies so as to ensure that research remains relevant and relatable to its stakeholders. As you peruse the five articles in this theme, we hope they stimulate curiosity and, more importantly, action to study and understand your own local and/or regional issues.

\section{Bibliography}

Abad, G.H. and Hidalgo, C.P. 2003. Our people's story: Philippine literature in English. Quezon City, Philippines: University of the Philippines Open University.

Anderson, B. 1983. Imagined communities: Reflections on the origin and spread of nationalism. London: Verso.

Arimbi, D.A. 2009. Reading contemporary Indonesian Muslim women writers: Representation, identity and religion of Muslim women in Indonesian fiction. Amsterdam: Amsterdam University Press. https://doi.org/10.5117/9789089640895

Ashcroft, B., Griffiths, G. and Tiffin, H. 1989. The empire writes back: Theory and practice in post-colonial literatures. London/New York: Routledge. https://doi. org/10.4324/9780203402627

Asl, M.P., Rajandran, K. and Yasir Azam, eds. 2019. Change and preservation in language and culture in Asia: e-Proceedings of the fifth international conference on linguistics, literature and culture (ICLLIC 2019). Pulau Pinang, Malaysia: School of Humanities, Universiti Sains Malaysia. Retrieved from http://humanities. usm.my/images/proceeding/E-proceedings-Icllic-2019-Full.pdf.

Asmah Haji Omar. 2014. The Mah Meri language. Selangor, Malaysia: University of Malaya Press.

Aveling, H. 2019. Perceptions: Essays on translation and literature of the Malay world. Selangor, Malaysia: Penerbit Universiti Kebangsaan Malaysia.

Azirah Hashim and Leitner, G., eds. 2020. English in Southeast Asia and ASEAN: Transformation of language habitats. Oxford: Routledge. 
Bachmann-Medick, D. 2016. Cultural turns: New orientations in the study of culture. Translated by A. Blauhut. Berlin: Walter De Gruyter. https://doi. org/10.1515/9783110402988

Bautista, M.L. and Bolton, K. 2008. Philippine English: Linguistic and literary perspectives. Hong Kong: Hong Kong University Press.

Bernards, B. 2015. Writing the South Seas: Imagining the Nanyang in Chinese and Southeast Asian postcolonial literature. Seattle/London: The University of Washington Press.

Bhatia, V., Gotti, M., Hashim, A., Koh, P. and Rajoo, S., eds. 2018. International arbitration discourse and practices in Asia. London: Routledge. https://doi. org/10.4324/9781315229799

Braginsky, V.I. 2004. The heritage of traditional Malay literature: A historical survey of genres, writings and literary views. Leiden: KITLV Press.

- 1993. The system of classical Malay literature. Leiden: KITLV Press.

Chatterjee, P. 1996. Whose imagined community? In Mapping the nation, ed. G. Balakrishnan, 214-225. London: Verso.

Chigas, G. 2005. Tum Teav: A translation and analysis of a Cambodian literary classic. Cambodia: Documentation Center of Cambodia.

Chin, G.V.S. Forthcoming. Translational politics in Southeast Asian literatures: Contesting race, gender and sexuality. London/New York: Routledge.

Chin, G.V.S. and Kathrina Mohd Daud. 2018. The Southeast Asian woman writes back: Gender, identity and nation in the literatures of Brunei Darussalam, Malaysia, Singapore, Indonesia and the Philippines. Singapore: Springer.

Deterding, D. 2013. Misunderstandings in English as a lingua franca: An analysis of ELF interactions in South-East Asia. Berlin: De Gruyter. https://doi. org/10.1515/9783110288599

_ 2007. Singapore English. Edinburgh: Edinburgh University Press. https://doi. org/10.3366/edinburgh/9780748625444.001.0001

Dewan Bahasa dan Pustaka. 2015. Kamus dewan. 4th Ed. Kuala Lumpur: Dewan Bahasa dan Pustaka.

Ding, C.M. and van der Molen, W., eds. 2018. Traces of the Ramayana and Mahabharata in Javanese and Malay literature. Singapore: ISEAS Publishing. https://doi. org/10.1355/9789814786584

Domigpe, J. and Domingo, N. 2015. Elementary Tagalog. Singapore: Tuttle Publishing.

Ebihara, M.M., Mortland, C.A. and Ledgerwood, J., eds. 1994. Cambodian culture since 1975: Homeland and exile. London: Cornell University Press. https://doi. org/10.7591/9781501723858

Enfield, N. 2007. A grammar of Lao. Berlin: Mouton de Grutyer. https://doi. org/10.1515/9783110207538

Ewing, M. 2005. Grammar and inference in conversation: Identifying clause structure in spoken Javanese. Amsterdam: John Benjamins. https://doi.org/10.1075/sidag.18

Foulcher, K., Moriyama, M. and Budiman, M., eds. 2012. Words in motion: Language and discourse in post-new order Indonesia. Singapore: NUS Press. 
Galam, R.G. 2009. The promise of the nation: Gender, history and nationalism in contemporary Ilokano literature. Quezon City, Philippines: Ateneo de Manila University Press.

Garcia, J.N.C. 2012. Aura: The gay theme in Philippine fiction in English. Pasig City, Philippines: Anvil Publishing Inc.

. 2009. Philippine gay culture: Binabae to bakla, silahis to MSM. 2nd Ed. Hong Kong: Hong Kong University Press.

- 2007. At home in unhomeliness: Rethinking the universal in Philippine postcolonial poetry in English. Manila: Philippine PEN.

- 1998. Slip/pages: Essays in Philippine gay criticism. Manila: De La Salle University Press.

Gill, S. K. 2002. International communication. Selangor, Malaysia: Universiti Putra Malaysia Press.

Goh, D.P.S., Gabrielpillai, M., Holden, P. and Khoo, G.C., eds. 2009. Race and multiculturalism in Malaysia and Singapore. London/New York: Routledge. https://doi.org/10.1163/9789401207089

Goh, R.B.H., ed. 2011. Narrating race: Asia, (trans)nationalism, social change. Amsterdam: Rodopi.

Groppe, A.M. 2013. Sinophone Malaysian literature: Not made in China. Amherst, NY: Cambria Press.

Hajar Abdul Rahim and Shakila Abdul Manan, eds. 2014. English in Malaysia: Postcolonial and beyond. Frankfurt: Peter Lang.

Halliday, M. 2010. Putting linguistic theory to work. In The collected works of M.A.K. Halliday, J. Webster (ed.), Vol. 11, 127-142. London: Bloomsbury.

Hau, C.S. 2004. On the subject of the nation: Filipino writings from the margin, 19812004. Quezon City, Philippines: Ateneo de Manila University Press.

- 2000. Necessary fictions: Philippine literature and the nation, 1946-1980. Quezon City, Philippines: Ateneo de Manila University Press.

Hellwig, T. 2012. Women and Malay voices: Undercurrent murmurings in Indonesia's colonial past. New York: Peter Lang. https://doi.org/10.3726/978-1-4539-0233-2

Hidalgo, C.P. 1998. A gentle subversion: Essays on Philippine fiction in English. Quezon City, Philippines: University of the Philippines Press.

- 1993. Philippine post-colonial studies: Essays on language and literature. Quezon City, Philippines: University of the Philippines Press.

Hijjas, M. 2010. Victorious wives: The disguised heroine in nineteenth-century Malay syair. Singapore: NUS Press.

Interlogue Series Collection. 1998-2009. Interlogue: Studies in Singapore literature, Volumes 1-8. Singapore: Ethos Books. Retrieved from https://www.ethosbooks. com.sg/products/interlogue-series-collection-8-volumes.

International Conference on Linguistics, Literature and Culture (ICLLIC). 2019. Homepage. Retrieved from http://www.icllic.usm.my/ (accessed 10 September 2020).

ICLLIC. 2016. Homepage. Retrieved from http://icllic2016.weebly.com (accessed 10 September 2020). 
2014. Homepage. Retrieved from http://icllic2014.weebly.com (accessed 10 September 2020).

. 2010. Homepage. Retrieved from http://web.usm.my/icllic2010 (accessed 10 September 2020).

Jackson, P.A. 2016. First queer voices from Thailand: Uncle Go's advice columns for gays, lesbians and kathoeys. Hong Kong: Hong Kong University Press. https://doi. org/10.5790/hongkong/9789888083268.001.0001

Jenny, M. and Tun, S.S.H. 2016. Burmese: A comprehensive grammar. London: Routledge. https://doi.org/10.4324/9781315651194

Juliana Othman and Maskanah Mohammad Lotfie, eds. 2018. Research design for language studies. Selangor, Malaysia: University of Malaya Press.

Koh, A. and Balasingamchow, Y.-M., eds. 2015. Women and the politics of representation in Southeast Asia: Engendering discourse in Singapore and Malaysia. Oxon: Routledge.

Koh, T.A. 2008. Singapore literature in English: An annotated bibliography. Singapore: National Library Board Singapore and Centre for Liberal Arts and Social Sciences, Nanyang Technological University.

Kularb, P. 2016. Reporting Thailand's Southern conflict: Mediating political dissent. London: Routledge. https://doi.org/10.4324/9781315727059

Langacker, R. 2013. Essentials of cognitive grammar. Oxford: Oxford University Press.

Lim, D.C.L. and Yamamoto, H. 2012. Film in contemporary Southeast Asia: Cultural interpretation and social intervention. London/New York: Routledge.

Lim, D.C.L., ed. 2008. Overcoming passion for race in Malaysian cultural studies. Amsterdam: Brill. https://doi.org/10.1163/ej.9789004168152.i-184

Lim, L., Pakir, A. and Wee, L. 2010. English in Singapore: Modernity and management. Singapore: NUS Press. https://doi.org/10.5790/hongkong/9789888028436.001.0001

Lim, S.G. 1994. Writing S.E./Asia in English: Against the grain, focus on Asian-Englishlanguage literature. London: Skoob Books Publishing.

-1993. Nationalism and literature: English-language writing from the Philippines and Singapore. Quezon City, Philippines: New Day.

Lindsay, J., ed. 2006. In between tongues: Translation and/of/in performance in Asia. Singapore: NUS Press.

Lo, J. 2004. Staging nation: english language theatre in Malaysia and Singapore. Hong Kong: Hong Kong University Press.

Low, E. and Azirah Hashim, eds. 2012. English in Southeast Asia: Features, policy and language in use. Amsterdam: John Benjamins. https://doi.org/10.1075/veaw.g42

Ly, B. 2020. Traces of trauma: Cambodian visual culture and national identity in the aftermath of genocide. Honolulu: University of Hawai'i Press. https://doi. org/10.2307/j.ctvgs08tz

Maier, H. 2004. We are playing relatives: A survey of Malay writing. Leiden: KITLV Press.

Mohamad Rashidi Pakri and Graf, A., eds. 2013. Fiction and faction in the Malay world. Newcastle upon Tyne, UK: Cambridge Scholars Publishing.

Mohammad A. Quayum and Wicks, P.C., eds. 2001. Malaysian literature in English: A critical reader. Selangor, Malaysia: Pearson Education. 
Muller, T., Herder, S., Adamson, J. and Brown, P., eds. 2012. Innovating EFL teaching in Asia. Basingstoke, England: Palgrave Macmillan. https://doi. org/10.1057/9780230347823

Murray, N. and Scarino, A., eds. 2014. Dynamic ecologies: A relational perspective on languages education in the Asia-Pacific region. Amsterdam: Springer. https://doi. org/10.1007/978-94-007-7972-3

Murtagh, B. 2013. Genders and sexualities in Indonesian cinema: Constructing gay, lesbi and waria identities on screen. London: Routledge. https://doi. org/10.4324/9780203796993

Nayyar, D. 2019. How Asia transformed from the poorest continent in the world into a global economic powerhouse. The Conversation, 17 September. Retrieved from https://theconversation.com/how-asia-transformed-from-the-poorest-continent-inthe-world-into-a-global-economic-powerhouse-123729.

Nelson, C., Proshina, Z. and Davis, D., eds. 2020. The handbook of World Englishes. Hoboken, NJ: Wiley Blackwell. https://doi.org/10.1002/9781119147282

$\mathrm{Ng}$, A.H.S. 2011. Intimating the sacred: Religion in English language Malaysian fiction. Hong Kong: Hong Kong University Press. https://doi.org/10.5790/ hongkong/9789888083213.001.0001

Nguyen-Marshall, V. 2008. In search of moral authority: The discourse of poverty, poor relief and charity in French colonial Vietnam. New York: Peter Lang.

Noor, F.A. 2019. Data-gathering in colonial Southeast Asia 1800-1900: Framing the other. Amsterdam: Amsterdam University Press.

Nor Faridah Abdul Manaf and Mohammad A. Quayum. 2003. Colonial to global: Malaysian women's writing in English 1940s-1990s. 2nd Ed. Kuala Lumpur: International Islamic University Malaysia (IIUM) Press.

Nurul Farhana Low bt Abdullah, Mohamad Rashidi Pakri and Abele, E., eds. 2015. Mapping the spectrum: Current and emerging perspectives in linguistics, literature and culture. Procedia - Social and Behavioural Sciences 200: 1-300.

Patke, R.S. and Holden, P. 2010. The Routledge concise history of Southeast Asian writing in English. London/New York: Routledge. https://doi.org/10.4324/9780203874035

Pennycook, A. 1994. The cultural politics of English as an international language. Singapore: Longman Publishers.

Pillai, S. 2020. Malaysian English. Berlin: Mouton de Grutyer.

- 2007. Colonial visions, postcolonial revisions: Images of the Indian diaspora in Malaysia. Newcastle upon Tyne, UK: Cambridge Scholars Publishing.

Pison, R.J.L. 2010. Dangerous liaisons: Sexing the nation in novels by Philippine women writers, 1993-2006. Quezon City, Philippines: The University of the Philippines Press.

Platt, M.B. 2013. Isan writers, Thai literature: Writing and regionalism in modern Thailand. Singapore: NUS Press/Denmark: NIAS Press. https://doi.org/10.2307/j. ctv1qv1fm

Poon, A. and Whitehead, A., eds. 2017. Singapore literature and culture: New directions in local and global contexts. London/New York: Routledge. https://doi. org/10.4324/9781315307756 
Puthucheary, R. 2009. Different voices: The Singaporean/Malaysian novel. Singapore: Institute of Southeast Asian Studies. https://doi.org/10.1355/9789812309129

Rajandran, K. and Shakila Abdul Manan, eds. 2019. Discourses of Southeast Asia: A social semiotic perspective. Singapore: Springer. https://doi.org/10.1007/978-98113-9883-4

Rappa, A. and Wee, L. 2006. Language policy and modernity in Southeast Asia: Malaysia, Philippines, Singapore and Thailand. New York: Springer. https://doi. org/10.1007/0-387-32186-1

Ricci, R. 2011. Islam translated: Literature, conversion and the Arabic cosmopolis of South and Southeast Asia. Chicago/London: The University of Chicago Press. https://doi.org/10.7208/chicago/9780226710907.001.0001

Salasiah Che Lah and Rita Abdul Rahman Ramakrishna, eds. 2019. Research mosaics of language studies in Asia: Differences and diversity. Pulau Pinang, Malaysia: Penerbit Universiti Sains Malaysia.

Shakila Abdul Manan and Hajar Abdul Rahim, eds. 2012. Linguistics, literature and culture: Millennium realities and innovative practices in Asia. Newcastle: Cambridge Scholars Publishing.

Sharifian, F. and Shakila Abdul Manan, eds. 2016. Linguistics, literature and culture: Interactions between the global and the local. KEMANUSIAAN the Asian Journal of Humanities 23(Supplement 2): 1-174.

Simpson, A., ed. 2007. Language and identity in Asia. Oxford: Oxford University Press.

Sinnott, M.J. 2004. Toms and dees: Transgender identity and female same-sex relationships in Thailand. Honolulu: University of Hawai'i Press. https://doi. org/10.1515/9780824865221

Slemon, S. 2015. The postcolonial turn. ESC: English Studies in Canada 41(4): 13. https:// doi.org/10.1353/esc.2015.0089

Smyth, D. 2014. Thai: An essential grammar. London: Routledge.

Smyth, D., ed. 2000. The canon in Southeast Asian literature: Literatures of Burma, Cambodia, Indonesia, Laos, Malaysia, Phillippines, Thailand and Vietnam. Richmond, Surrey: Curzon Press.

Smyth, D. and Kien, T. 1995. Tuttle practical Cambodian dictionary. Singapore: Tuttle Publishing.

Sneddon, J., Adelaar, A., Djenar, D. and Ewing, M. 2010. Indonesian: A comprehensive grammar. London: Routledge.

Stockwell, P. 2019. Cognitive poetics. London: Routledge. https://doi. org/10.4324/9780367854546

Suryadinata, L., ed. 1993. Chinese adaptation and diversity: Essays on society and literature in Indonesia, Malaysia and Singapore. Singapore: Singapore University Press, National University of Singapore.

Tan, E.K. 2013. Rethinking Chineseness: Translational sinophone identities in the Nanyang literary world. Amherst, NY: Cambria Press.

Tan, Y.Y. and Lindsay, J. 2003. Babel or Behemoth: Language trends in Asia. Singapore: NUS Press.

Tay, E. 2011. Colony, nation and globalisation: Not at home in Singaporean and Malaysian literature. Hong Kong: Hong Kong University Press. 
Tope, L.R.R. 1998. (Un)framing Southeast Asia: Nationalism and the post-colonial text in English in Singapore, Malaysia and the Philippines. Quezon City, Philippines: University of the Philippines Press.

United Nations Development Programme. 2020. The 2020 global multidimensional poverty index. Oxford: United Nations Development Programme and Oxford Poverty and Human Development Initiative. Retrieved from http://hdr.undp.org/ en/2020-MPI.

Wai, S. H. 2019. Remapping the sinophone: The cultural production of Chinese-language cinema in Singapore and Malaya before and during the Cold War. Hong Kong: Hong Kong University Press.

Wong, Y.W. 2002. Post-colonial Chinese literatures in Singapore and Malaysia. Singapore: Department of Chinese Studies, National University of Singapore/ Global Publishing. https://doi.org/10.1142/g078

Yamada, T.S., ed. 2009. Modern short fiction of Southeast Asia: A literary history. Ann Arbor, Michigan: Association for Asian Studies.

Yendamuri, P. and Ingilizian, Z. 2019. In 2020 Asia will have the world's largest GDP. World Economic Forum, 20 December. Retrieved from https://www.weforum.org/ agenda/2019/12/asia-economic-growth/.

Yue, A. and Zubillaga-Pow, J., eds. 2012. Queer Singapore: Illiberal citizenship and mediated cultures. Hong Kong: Hong Kong University Press. https://doi. org/10.5790/hongkong/9789888139330.001.0001

Zawiah Yahya. 2010. Reading approaches in Malay literature. Selangor, Malaysia: Penerbit Universiti Kebangsaan Malaysia.

- 1994. Resisting colonialist discourse. Selangor, Malaysia: Penerbit Universiti Kebangsaan Malaysia.

Zuraidah Mohd Don. 2011. English in multicultural Malaysia. Selangor, Malaysia: University of Malaya Press. 